\title{
Response of Islamist ond Holders of Sunda Wiwitan Against Wedding a Different Religion
}

\author{
Iman Sucipto1*, Yana Mulyana², Yudi Guntara ${ }^{3}$ \\ ${ }^{1}$ UIN Sunan Gunung Djati Bandung \\ 2 STAI Al Falah Cicalengka Bandung \\ ${ }^{3}$ Sekolah Tinggi Ilmu Dakwah (STID) Sirnarasa, Ciamis, Jawa Barat \\ *Corresponding author E-mail: imamsucipto23@gmail.com
}

\begin{abstract}
The purpose of this study was to determine the response of a pair of followers of Islam and Sundanese Wiwitan to interfaith marriages in Cigugur. This research uses descriptive analysis method with a qualitative approach. Whereas the framework for thinking uses the grand theory of Joachim Wach, middle of the Ninian Smart theory and the applicative theory of phenomenology of Edmund Husserl. The results showed that the response of interfaith marriages was as follows: Interfaith marriages were a hidden truth, Embodiments of compassion, differences were a necessity, human rights, feelings of tumarima, strong mentality, and not recognition but understanding.
\end{abstract}

Keywords: Islamic religion, interfaith marriages, Sundanese wiwitan, response

\section{INTRODUCTION}

The unitary state of the republic of Indonesia (NKRI) is one of the countries with a pluralist and diverse ethnic composition in the world (Firdaus, 2014). The nation, which is spread over 13,000 large and small islands, consists of hundreds of ethnicities, religions, cultures and customs, and speaks hundreds of unique regional languages. This makes the orientation of regional culture and life outlook also varied. All aspects of socio-cultural diversity that makes Indonesia a nation with a high level of diversity. Atho Mudzakir explained that the plurality of Indonesian society has a characteristic characterized by its vertical and horizontal characteristics . Vertical characteristics are another picture of the structure of Indonesian society that shows the existence of a stratified and stratified social layer in society. Horizontal characteristics can be seen in the existence of social entities that have a number of differences that are considered equal in the social structure of society, such as differences in race, ethnicity, customs, traditions, and religion (St Aisyah, 2014).

Among the religions in Indonesia, local religion is the religion whose dynamics are studied the most. There are a number of local belief systems in Java, such as Sundanese Wiwitan. Central Sundanese wiwitan is in Cigugur Kuningan, West Java. According to the population data of Cigugur village on December 31, 2017 there were 7,394 people or people or around 2,324 households. In Cigugur live various ethnicities, such as Sundanese, Javanese, Madurese, Batak, Malay or Minang, Bugis or Makassar, East or Maluku or Papua. Cigugur based on religion, 4,434 followers of Islam, 2,706 Catholics, 277 Christians, 2 Hindus, 4 Buddhists, and Believers or Dawa Javanese religion, or Sundanese wiwitan 184 people.

Based on ethnic and religious diversity, interfaith marriages took place in Cigugur. Surely this is worth investigating how the response of the Muslim and Sundanese Wiwitan couple is related to this matter.

Several studies have discussed about interfaith marriages, including the legality of interfaith marriages in Law number 01 of 1974 concerning marriage and Law number 23 of 2006 concerning

* Copyright (c) 2020 Iman Sucipto et.all

This work is licensed under a Creative Commons Attribution-ShareAlike 4.0 International License.

Received: May 05, 2020; Revised: July 30, 2020; Accepted: July 31, 2020 
marriage. This research was conducted by Yunus \& Aini (2020), other than that some other studies such as research by Lokawijaya \& Mulati (2019) which discusses interfaith marriage seen from law number 1 of 1974 and research by Nurlizam (2019) which sees interfaith marriage through the view of the Koran and the law.

These studies are related to interfaith marriages in Indonesia in various perspectives, there are also studies whose object is Cigugur. Seeing that research, it is known that from the many studies on Cigugur, there hasn't been any literature that discusses how the adherents of Islam and Sundanese Wiwitan in Cigugur to marriages of different religions. And that will be the differentiator of this research with other research.

\section{METHODOLOGY}

Research on social phenomena (Ahimsa-Putra, 2012), or social research (social research), in general is more aimed at finding an understanding (understanding, verstehen) that is intact to the phenomenon under study. While this research uses descriptive analysis methodology and supported theory (Sugiyono, 2013), (1) the main theory is universal (Gerand Theori), (2) intermediate theory which is to explain the research problem (Middle Theori, (3) applicative theory to explain the operationalization of theory and problem objects research (Apply Theori) The theoretical scheme that will be built in this study:

In accordance with the framework of thinking that will be discussed below as an approach to research theory. Furthermore, the researcher will explain the three uses of the theory, namely:

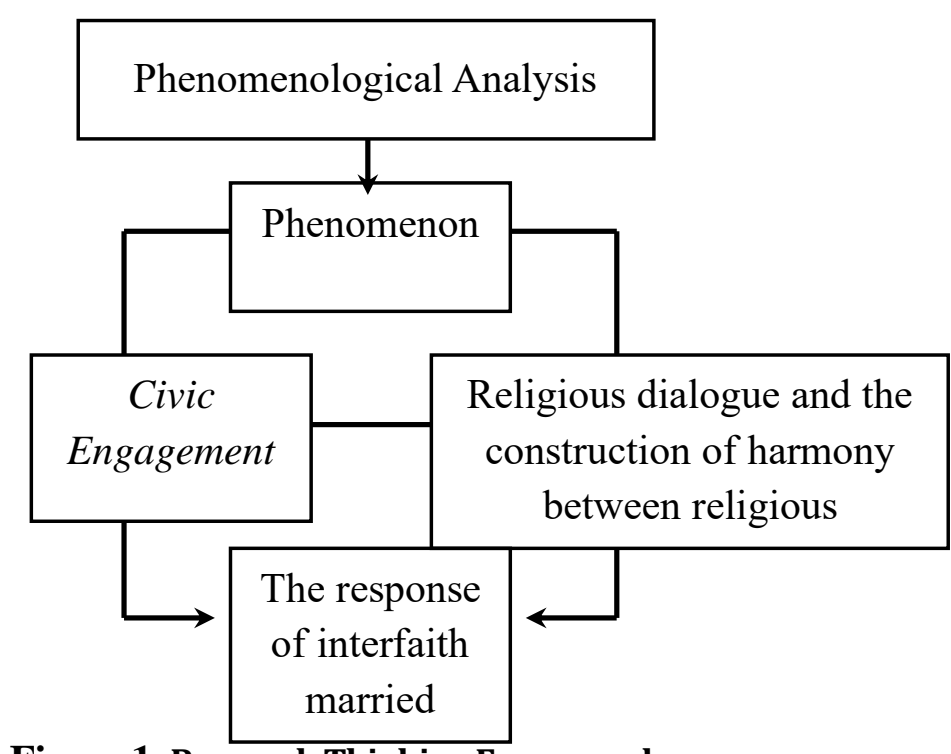

Figure 1. Research Thinking Framework

\section{RESULTS AND DISCUSSION}

\section{Frofile cigugur brass, West Java}

Cigugur Village is a village located in Kuningan District, West Java. The village is a holiday destination in Kuningan, tourists can come from cities outside the Kuningan district but from other areas 
as well, where the lives of the cigugur Kuningan people mostly work as farmers because agricultural life is suitable for those whose fields are paddy fields and fields so that the work is the economic support.

In the village of Cigugur there are some beliefs but these streams of belief do not make them hate each other but they always respect each other and respect the trust of the people who follow and coexist peacefully until now (Yusuf, 2014). There are several traditions of the cigugur community to always maintain peace in their area such as holding a seren taun ceremony, which is owned by Sundanese agrarian community which aims as gratitude for the blessings they receive.

Tolerance and pluralism can be seen in the funeral procession in the village of Cigugur where every community who died was divided into groups of their respective beliefs. The entry of Christianity which became one of the religions in the village of Cigugur even added diversity in the village including in the field of livelihood (Syaripulloh, 2014).

\section{Islam}

Islam is a perfect religion, whose main mission is to make humans a creature of noble character. To achieve this, Allah (swt) sent the Prophet Muhammad accompanied by the Koran as a guide for Muslims who are reflected by his noble character, as uswatun hasanah, as explained in the Koran:

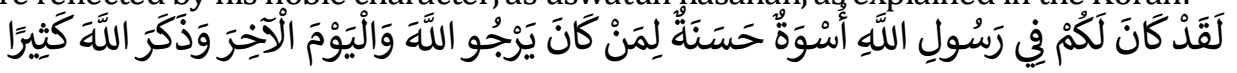

"Indeed, the Prophet (s) is a good role model for you (that is) for those who hope for (the mercy) of Allah and (coming) on the Day of Resurrection and he often mentions Allah. "(Surat al-Ahzab [33]: 21)

Indonesia is a country with a majority of Islamic society (Paridi, 2019), Islam itself has determined what things are forbidden and in the permits that we used to debut is halal and haram.

In the context of Islamic interfaith marriages are still being debated which leads to the polytheists and Ahl-al-Kitab that already exist in the Qur'anic text. There are several views about marriages that convert to religion which states that the religion of Islam is perfect and the existing regulations in the Koran are final and are final that is also strengthened by verses of the Koran such as an.nahl: 89. But those who accept interfaith marriages are based on religious texts do not stand alone without the interference of space and time (Misrawi, 2010). The purpose of space time here is in the interpretation of the verses of the Koran should be studied more deeply based on the context and time as well as the meaning to be explained in it

\section{Sundanese wiwitan}

Sundanese wiwitan can be said also with local religion or can also be called the flow of belief, this belief is believed to have existed even since the discovery of major religions such as Islam, Hinduism, Buddhism and others (Indrawardana, 2014). Judging from the syllable "Sunda Wiwitan" consists of two words: Sundanese and Wiwitan. The term 'Sundanese' can (according to P. Djatikusumah) be interpreted in three basic conceptual categories, namely: (1) philosophical: Sundanese means bodas (white), clean, light, beautiful, good, beautiful, good and so on; (2) ethnicity: Sundanese means or refers to the Sundanese tribal community that God created as well as other tribes and nations on earth. In this case related to Sundanese culture which is inherent in the ways and characteristics of Sundanese people; (3) geographical: Sunda means referring to the naming of an area based on a world map from the past to the territory of Indonesia (the Archipelago), namely as the level of the 'Greater Sunda' region (The Greater Sunda Islands) covering a large set of islands (Sumatra, Java, Madura, Kalimantan) and 'Lesser Sunda' (The Lesser Sunda Islands), which are a series of smaller islands located east of Java (Bali, Lombok, Flores, Sumbawa, Sumba, Roti, etc. wiwitan can also be interpreted as a origin, therefore Sundanese wiwitan can 
also be interpreted as a beginning starting from the beliefs formed from philosophical, ethnic and geographical.

Some of the teachings in Sunda Wiwitan such as teaching the concept of God, humans and mystics towards human beings senjati, pikukuh tilu and customary law, marriage and death.

In perihih teachings - teachings from the Sunda Wiwitan creed contains a single beginning of the end so sawaji which means the beginning of one, the end of being together / united. Where the flow of this belief considers that marriage is not only as worship and proves love for the universal god but is a way that makes humans able to maintain offspring, protect nature to get the perfection of life.

\section{The Response of Muslims And Sundanese Wiwitan To Different Marriage Marriage}

Islam and the beliefs of Sunda Wiwitan have some responses to interfaith marriages, in Islam there are two responses that still do not allow interfaith marriages and some are still in doubt while in Sunda Wiwitan it can be concluded that in Sunda Wiwitan considers that marriage is a the beginning to unite the two men and women which aims to maintain the serenity and preserve nature in order to achieve a perfect life, in marriage in the Sunda Muslim sect and Islam must still have permission from the parents of the bride and groom which with the agreement then the couple can proceed to the next stage.

In Islam marriage is also a worship where there are separate rules in Islamic law, the similarity of the meaning of Islamic religion and Sundanese beliefs, both believe that marriage is a worship which forms a physical and spiritual bond between men and women (Atabik \& Mudhiiah, 2016).

Wedding between adherents of Islam and adherents of the flow of belief has also often occurred and in its implementation the result of deliberation and agreement between the two traditional and cultural parties which will be followed. The difference in the process of marriage between the religion of Islam and the Sundanese faith stream is in the Kabul consent process.

the response of interfaith marriage couples found with interfaith marriage is a hidden truth, embodiment of affection, difference is a necessity, human rights, a feeling of homage tumarima, strong mentally, and not of recognition but of understanding

\section{CONCLUSION}

This study can be concluded that the response of interfaith marriages between Islam and Sunda Wiwitan in Cigugur argues that interfaith marriages are a hidden truth, the embodiment of affection (feeling the gift of love), difference is a necessity, human rights, a sense of tumarima, strong sense of tumarima, strong mentally, and not acknowledgment but understanding. With the results of these studies, it can add to the scientific treasures and references for researchers to participate in the same research, the same object or develop the research on different variables and locations.

\section{REFERENCES}

Ahimsa-Putra, H. S. (2012). Fenomenologi Agama: Pendekatan Fenomenologi Untuk Memahami Agama. Walisongo: Jurnal Penelitian Sosial Keagamaan, 20(2), 271-304.

Atabik, A., \& Mudhiiah, K. (2016). Pernikahan Dan Hikmahnya Perspektif Hukum Islam. Yudisia: Jurnal Pemikiran Hukum Dan Hukum Islam, 5(2).

Firdaus, M. A. (2014). Eksistensi Fkub Dalam Memelihara Kerukunan Umat Beragama Di Indonesia. Kontekstualita: Jurnal Penelitian Sosial Keagamaan, 29(1), 145717.

Indrawardana, I. (2014). Berketuhanan Dalam Perspektif Kepercayaan Sunda Wiwitan. Melintas, 30(1), 105-118. 
Lokawijaya, A. F., \& Mulati, M. (2019). Analisis Penetapan Pengadilan Negeri Surakarta No. 46/Pdt. P/2016/Pn. Skt Terkait Perkawinan Beda Agama Ditinjau Berdasarkan Undang-Undang No. 1 Tahun 1974. Jurnal Hukum Adigama, 2(2), 434-458.

Misrawi, Z. (2010). Pandangan Muslim Moderat: Toleransi, Terorisme, Dan Oase Perdamaian. Penerbit Buku Kompas.

Nurlizam, N. (2019). Pernikahan Beda Agama Dalam Perspektif Al-Quran Dan Hukum Positif Di Indonesia. Jurnal Ulunnuha, 8(2), 267-290.

Paridi, A. (2019). Implementasi Program Pengembangan Karakter Islami Melalui Program Tahfidz. Khazanah Pendidikan Islam, 1(1), 12-21.

St Aisyah, B. M. (2014). Konflik Sosial Dalam Hubungan Antar Umat Beragama. Jurnal Dakwah Tabligh, 15(2), 189-208.

Sugiyono. (2013). Metode Penelitian Pendidikan Pendekatan Kauntitatif, Kualitatif Dan R\&D. Bandung: Alfabeta.

Syaripulloh, S. (2014). Kebersamaan Dalam Perbedaan: Studi Kasus Masyarakat Cigugur, Kabupaten Kuningan, Jawa Barat. Sosio-Didaktika: Social Science Education Journal, 1(1), 64-78.

Yunus, F. M., \& Aini, Z. (2020). Perkawinan Beda Agama Dalam Undang-Undang Nomor 23 Tahun 2006 Tentang Administrasi Kependudukan (Tinjauan Hukum Islam). Media Syari'ah, 20(2), $138-158$.

Yusuf, A. S. (2014). Kerukunan Umat Beragama Antara Islam, Kristen Dan Sunda Wiwitan: Studi Kasus Kelurahan Cigugur Kecamatan Cigugur, Kuningan-Jawa Barat. 